\title{
ISOTOPIC STUDIES OF THE CARBONATE VEINS OF THE CABAÇAL MINE, MATO GROSSO, BRAZIL
}

\author{
FRANCISCO E. C. PINHO* \& WILLIAM S. FYFE**
}

\begin{abstract}
RESUMO ESTUDOS ISOTOPICOS DE VEIOS DE CARBONATO DA MINA CABACAL, MATO GROSSO, BRASIL O depósito de ouro do Cabaçal esta hospedado em rochas volcanoclasticas do Greenstone Belt do Alto Jauru. Associados a este deposito, ocorrem veios de calcita e de quartzo-calcita. Observações de campo e dados de isotopos estaveis de oxigenio e carbono e de razoes Sr/ Sr, possibilitaram a divisão destes veios em dois grupos, sendo um de formas lenticulares a suavemente sigmoidais e que corta a foliafao principal com baixo angulo, e outro formado por enxames de finos veios que tombem cortam a foliacao principal, porem com angulos proximos a $90^{\circ}$. Dados de isdtopos estaveis de oxigênio e carbono e de razões de ${ }^{87} \mathrm{Sr}{ }^{86} \mathrm{Sr}$ dos veios indicam que o carbonate do primeiro grupo de veios, bem como os veios de carbonato-quartzo sao relacionados a processes ígneos. O carbonate dos veios do segundo grupo sao supostamente formados por fluidos metamorficos ou por fluidos meteoricos que percolaram e reagiram com as rochas encaixantes e preencheram fraturas de extensao, apos a atividade tectonica.
\end{abstract}

Palavras-chaves:

ABSTRACT The Cabaçal gold mineralizations are enclosed within Volcaniclastic rocks of the Alto Jauru Greenstone Belt. Carbonate and quartz-carbonate veins are common associated with the mineralized zone. Calcite is the only carbonate mineral in these veins that are divided in two groups: lenticular or slightly sigmoidal veins that cross cut the main schistosity in a low angle, and fine veins that occur in swarms, cross cut the main rock schistosity, but in a high angle $\left( \pm 90^{\circ}\right)$. Carbon and oxygen isotope data, as well as ${ }^{87} \mathrm{Sr} / \mathrm{Sr}{ }^{86} \mathrm{ratios}$ of the Cabacal carbonate veins indicate that the first group of veins, and the quartz-carbonate veins are related to igneous processes. The second group is believed to have been formed by metamorphic or meteoric fluids, which percolate through extension fractures and interacted with the country rocks after the cessation of the tectonic processes.

Key-words:

INTRODUCTION The Cabaçal gold deposit is located in the southern part of the Amazonian Craton, 30Km from the Araputanga township, state of Mato Grosso, mid-west Brazil. The Cabafal mine started production in 1987 and interrupted in 1991.

Four major carbonate generations are recognized in the rocks from

i) calcite as a secondary mineral from alteration of ferromagnesian minerals by hydrothermal alteration, a common process affecting host rocks, ii) Calcite in the chlorite zone (ZC1), iii) quartz-carbonate veins, and iv) carbonate veins.

Carbon and oxygen isotope data and ${ }^{87} \mathrm{Sr} /{ }^{86} \mathrm{Sr}$ ratios were obtained for calcite from carbonate veins and from quartz-carbonate vein samples. These data will be interpreted in the following sections and resulting implications, with respect to the possible source of the fluids will be discussed.

Calcite samples were hand crushed and reacted with $100 \%$ phosphoric acid $\left(\mathrm{H}_{3} \mathrm{PO}_{4}\right)$ for $1 \mathrm{hr}$ at $25^{\circ} \mathrm{C}$ (modified method of McCrea 1950). An OPTIMA mass spectrometer was used to perform the isotopic analyses. Results were calculated using the phosphoric acid$\mathrm{CO}_{2}$ fractionation factor $(1.01025$, modified after Sharma and Clayton 1965).

\section{GEOLOGICAL SETTING AND MINERALIZATION The}

Cabagal mineralizations are enclosed within a sequence of tuffs and Volcaniclastic rocks, with layers of chert and ferruginous chert, near the boundary with a tuffaceous/porphgritic metavolcanic unit (TAC/VAP). The stratigraphic units in the Caba?al are the Early Proterozoic units from the Alto Jauru Greenstone Belt and the Late Proterozoic Cabafal Gabbro Sill (Fig. 1). The Cabaçal deposit and others deposits nearby are hosted in banded chert metatuffs and banded cherts from the Manuel Leme Formation. During the drilling program and mining operation, a stratigraphic sequence was identified for the mine. Because the mine sequence is very deformed and pervasively foliated, a clear lithological subdivision is difficult to make. A typical stratigraphic sequence for the Cabaçal deposit consists of a volcanochemical unit, a chloritized zone, and a volcano-volcaniclastic unit.

Well-defined features bound the mineralized zone at Cabagal on at least three sides. A NE fault defines the southwestern bounds, a gabbro sill bounded the northeast limit, a transition between altered mineralized rock to weakly altered rock defines the southwest boundary (Mason and Kerr 1 990), and finally the northwest limit that is not well defined by a NE fault system.

Three ore zones with irregular shape and undulating outlines have been defined (Mineracao Santa Marta S.A. 1987). These three zones are coincident with the principal schistosity $\mathrm{S}_{1}$, and plunge in two directions (coincident with S1 :SW with variable dip, and S-SE dipping about $20^{\circ}$ ). The second plunge is coincident with the axial zone of DI folding.

Mason and Kerr (1990) associated the three ore zones with three hydrothermal centers called South Copper Zone (SCZ), Central Cop-

* Universidade Federal de Mato Grosso-Brazil. (egidio@cpd.ufmt.br).

** University of Western Ontario-Canada (mmahaom@julian.uwo.ca) per Zone (CCZ), and East Copper Zone (ECZ). The stringer zones from these three hydrothermal centers become gradually weaker in terms of mineralization and hydrothermal alteration towards northwest (Mason and Kerr 1990).

The three zones show different characteristics with respect to alteration, mineral composition and gold grades. Only the CCZ shows massive sulphide mineralization. The massive sulphide ore caps the alteration pipe, and a banded tuff (chert) separates this mineralization from the stringer zone in the $\mathrm{CCZ}$.

The zinc zonation in the CCZ shows a bared core coincident with the ZCL pipe, surrounded by a broad zone of anomalous values, which has been interpreted as typical zonation with a hotter zone in the throat of the pipe, and cooler areas around it (Mason and Kerr 1990).

Gold distribution is erratic relative to the different zones. However, the highest grades are related to the South Copper Zone. Locally, different structural features or paragenetic associations show grades up to $100 \mathrm{~g} / \mathrm{t} \mathrm{Au}$. One example of this is evident at level 195 in the SCZ, where gold in visible grains is associated with a chlorite zone rich in garnet. In terms of remobilization related to structural features, sulphides rich in gold occur in the core of the F2 folds, all over the area (Pinho 1996).

OCCURRENCE OF CARBONATE VEINS The main schistosity at Cabaçal has, in general, a N30W strike and a dip of 50SW. Carbonate veins are millimeters to centimeters in width and show different orientations. Most of them crosscut the main schistosity (Fig. 2).

Carbonate veins are widespread in different areas and in different rocks of the mine. They exist in felsic volcanics, volcaniclastics, and chloritic alteration zones, and they fill extensional fractures generated during the latest or post-metamorphic stage. In general, it is possible to differentiate two groups of carbonate veins:

1) veins occurring as a lenticular or slightly sigmoidal shape. Usually they are $15-80 \mathrm{~cm}$ long and $5-15 \mathrm{~cm}$ wide, and cross cut the main schistosity. White and pink calcite is the main component, however, sulfides including pyrite, chalcopyrite and galena, and some gold occur.

2) Veins at an average width of $2 \mathrm{~cm}$, which occur in swarms in which the veins have 10-20 cm spacing. They, also, crosscut the main rock schistosity, but with a high angle of around $90^{\circ}$. Apophyses from these veins are present and may be concordant to schistosity. White calcite is the main component, although some host rock fragments are present.

CARBONATE CHEMISTRY The chemical composition of the carbonate was determined by electron microprobe. X-ray diffraction was used to check the calcite purity. Calcite was the only carbonate mineral determined.

Data plotted in the ternary diagram of figure 3, show certain clusters. FeO values range between zero and $2.25 \%$. Only sample SN1401 has values above $1.00 \%$. MnO values range from 0.49 to 


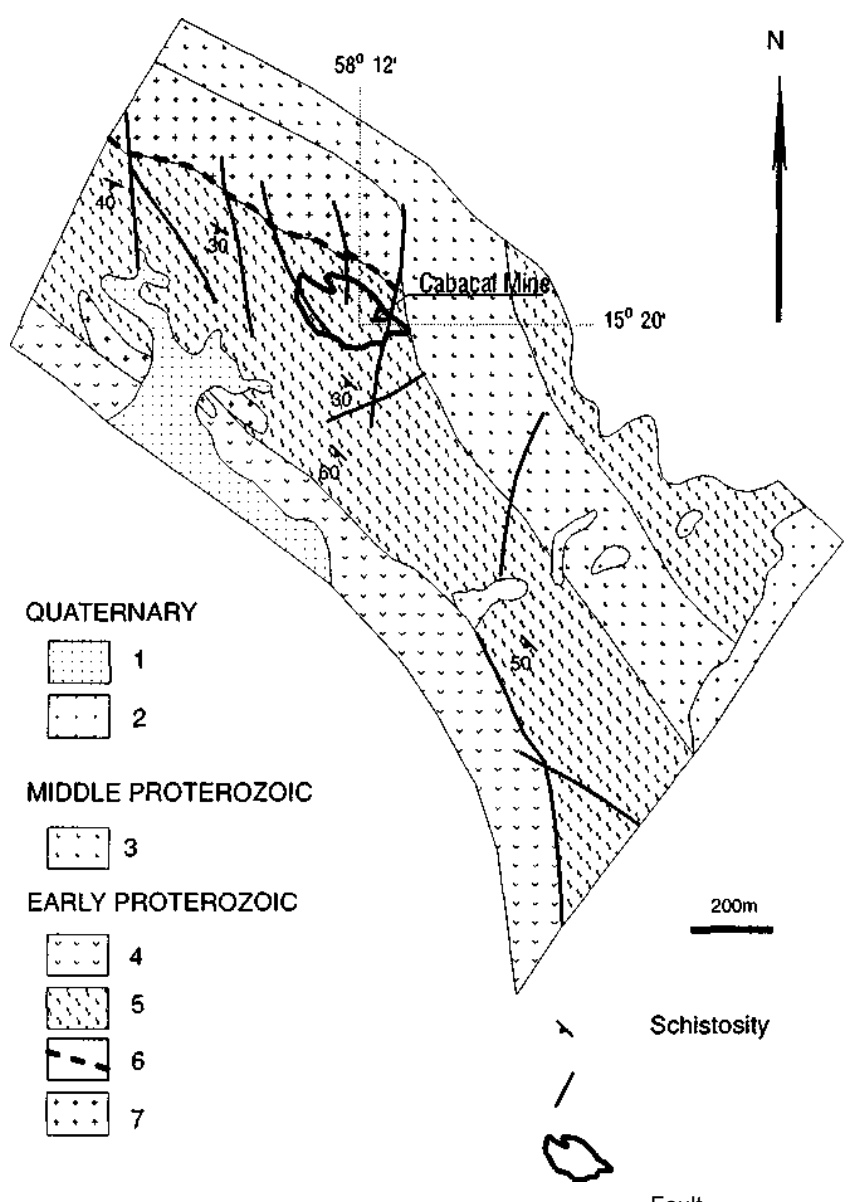

Fault

Surface projection of ore zones

Figure 1 - Geologic map of the Cabaçal Mine area. 1. Alluvium, 2. Colluvial from the Aguapei Group, 3. Cabaçal gabbro Sill/Dike, 4. Metabasic and intermediate volcanic rocks, 5. Banded cherts metatuffs and banded cherts. Intercalation of metadacitic lava flows, 6. Chloritizedzone, and 7. Metatuffs, porphyritic dacitic lava flows.

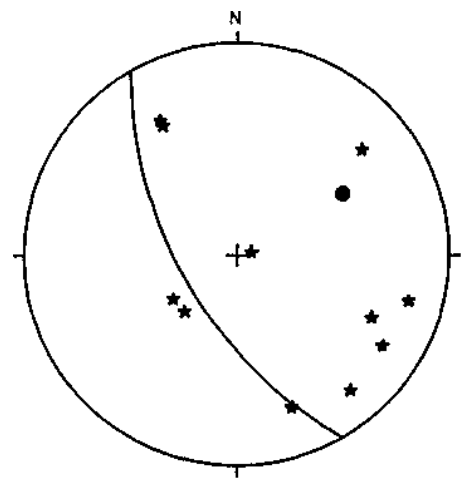

Figure 2 - Stereographic projection showing the average orientation of the main schistosity and carbonate vein systems in Cabaçal mine, plotted in Wulf stereonet. Main schistosity pole in circle, carbonate vein poles in stars, plan represents main schistosity.

$0.92 \%$ and $\mathrm{MgO}$ from zero to $0.92 \%$. Sample SN1401 is the richest in these two oxides. $\mathrm{CaO}$ varies from 51.17 to $56.07 \%$. Low values in $\mathrm{CaO}$ correlate with high values of $\mathrm{FeO}, \mathrm{MnO}$, and $\mathrm{MgO}$. $\mathrm{SrO}$ is present in the sample SP70-34.20 with values that range from 0.1 to $0.7 \%$.

Petrographic and microprobe studies have detected the presence of fluorite and pyrite in the carbonate veins. Fluorite occurs as later fractures fill, or is present as small triangular crystals. It is a major component in sample SN110.

ISOTOPIC COMPOSITION Carbon and oxygen isotope data, as well ${ }^{87} \mathrm{Sr} /{ }^{86} \mathrm{Sr}$ ratios of the Cabaçal vein calcite are presented in Table 1. The $8{ }^{13} \mathrm{C}$ ratios show a wide range of -10.78 to -3.027 oo relative to
PDB. Also, the $\delta^{18} \mathrm{O}$ ratios have a large variation, ranging from 7.62 to $18.03 \%$ oo relative to SMOW.

Results plotted in the diagram $\delta^{13} \mathrm{C}$ versus $\delta^{18} \mathrm{O}$ (Fig. 4), show that samples from the first group and from the quartz-carbonate veins have similar $\delta^{13} \mathrm{C}$ and $\delta^{18} \mathrm{O}$ ratios. These samples plot in the magmatic $\mathrm{CO}_{2}$ field but the sample SP76-101.10 that shows a higher $\delta^{18} \mathrm{O}$ value.

Histograms of the $\delta^{13} \mathrm{C}$ and $\delta^{18} \mathrm{O}$ data of the Cabafal samples show the isotopic ratios to vary between -7 and $-5 \%$ o relative to PDB and 7 to $9 \%$ o relative to SMOW, respectively (Fig. 5). On a $\delta^{13} \mathrm{C}$ versus $\delta^{18} \mathrm{O}$ diagram, most of the samples lie in general within or close to the $\mathrm{CO}_{2}$ field, and to the gold occurrence field (Fig. 4).

Ohmoto and Rye (1979) stated that the range of $\delta^{13} \mathrm{C}$ of most of the carbonate veins $(-8$ to $-4 \%$ oo is consistent with deep-seated carbon as compared to analyses from igneous rocks. In contrast, Bethke and Rye (1979) argued that values of -8 to $-5 \%$ oo have been observed in hydrothermal and carbonate minerals from ore deposits in all types of rocks, irrespective of whether or not carbonate rocks are present.

Burrows et al. (1986), interpreting $\delta^{13} \mathrm{C}$ histograms from $14 \mathrm{Au}-$ mineralized locations in the Timmins area, found a concentration of values ranging from -5 to $-3 \%$, and concluded that the Archaean gold-quartz vein mineralization is of a magmatic origin. This evidence also agrees with Wood (1980) who stated that domal tonalite gneissegranodirite-quartz monzonite-type material which intruded the lower parts of Archaean greenstone belts, could constitute an indirect, or direct fluid source to generate mineralizations in that region.

The carbon and oxygen isotopic data from the first group of veins and from the quartz-carbonate veins from the Cabaçal deposit suggest that deep-seated, probably magmatically derived fluids may have created these veins. Problems related to quartz-carbonate vein analyses must be considered. Due to the low percentage of calcite in the quartz-carbonate veins (less than $2 \%$ ), the quantity of produced $\mathrm{CO}_{2}$ was very small, causing problems during sample preparation on the vacuum line. However, samples were analyzed in duplicates and show consistent results.

${ }^{87} \mathrm{Sr}{ }^{86} \mathrm{Sr}$ ratios from calcite veins in the Cabaçal mine vary between 0.7029 and 0.7144 (Table 1). These range points to a contribution from mantle like to continent-derived sediments, or reworked crustal materials. Notwithstanding, only two samples from the first group were analyzed for ${ }^{87} \mathrm{Sr}{ }^{86} \mathrm{Sr}$ ratios, and these show a consistently low value of 0.7029 . These data clearly confirm the above idea, concluded from $\delta^{13} \mathrm{C}$ and $\delta{ }^{18} \mathrm{O}$ data, in which magmatic fluids could be the source for the generation of the carbonate veins from the first group.

Faure and Hurley (1963) observed that the enrichment in radiogenic ${ }^{87} \mathrm{Sr}$ in the continental crust contrasts sharply with the much lesser increase of the ${ }^{87} \mathrm{Sr}{ }^{86} \mathrm{Sr}$ ratio in the upper mantle. The identification of this difference was helpful in permitting the identification of crustal-derived strontium (elevated $\mathrm{Sr}^{86} \mathrm{Sr}$ ratio), and to distinguish it from mantle-derived strontium.

Between 2.5 and $1.0 \mathrm{OGa},{ }^{87} \mathrm{Sr} /{ }^{86} \mathrm{Sr}$ values for the mantle have been estimated to be between 0.7025 and 0.7035 (Faure and Powell 1972). Rocks from the Cabaçal Belt and the carbonate veins within them were deposited in this period. Therefore, the value of 0.7029 of the carbonate veins of the first group is compatible with mantle-derive $\mathrm{Sr}$ values during the time of their deposition.

INTERPRETATION From the data available at present, it is impossible to precisely determine the timing of the generation of the first group of carbonate veins. Four major magmatic processes occurred in the region: deposition of the volcanic sequence (hosting veins), Cabacal Tonalite intrusion, Alvorada Granite intrusion and the Cabaçal Gabbro Sill/Dike intrusion. The relationship between the last three processes and the carbonate veins has, as yet, not been established.

Intrusive rocks and orthogneisses in the region are mantle related (Fig. 6). ${ }^{87} \mathrm{Sr} /{ }^{86} \mathrm{Sr}$ values from the first carbonate vein group coincide with values from local rocks such as granites, tonalites and orthogneisses (Fig. 6). This indicates a hydrothermal juvenile fluid associated with these carbonate vein generation. ${ }^{87} \mathrm{Sr} /{ }^{86} \mathrm{Sr}$ ratios clearly point to the presence of magmatic waters in these processes.

The veins of the second generation show a wide variation and an increase in $\delta^{18} \mathrm{O}$ values. Value range from 8.20 to $18.03^{\circ} \%$, but only one value is below 10.4 and only one is above $15.99 \%$ oo. The $\delta^{13} \mathrm{C}$ values are variable too, ranging from -10.78 to $-3.02 \%$ oo.

$\delta^{18} \mathrm{O}$ variation of -1.8 to $5.2^{\%} \% \mathrm{o}$ was found in calcite veins from the Stony Mountain Complex (Forester and Taylor 1980). They suggest that the $\delta^{18} \mathrm{O}$ variations of the carbonates in that area is best explained 

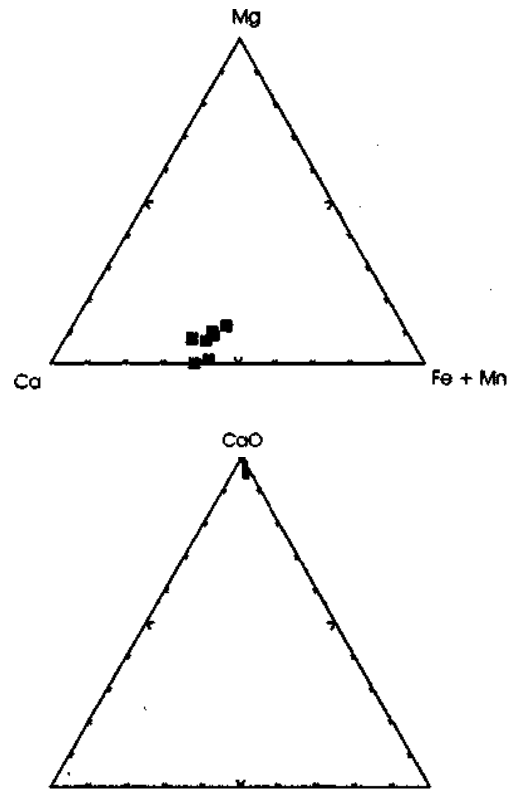

$\mathrm{MgO}$

Fed

Figure 3 - $\mathrm{Mg}-\mathrm{Ca}-\mathrm{Fe}+\mathrm{Mn}$ and $\mathrm{CaO}-\mathrm{MgO}-\mathrm{FeO}$ ternary diagrams with chemical composition of the calcite veins from the Cabaçal mine.

by varying ${ }^{18} \mathrm{O} /{ }^{16} \mathrm{O}$ ratios of the meteoric ground waters. Exchange between those waters with rocks in the Stony Mountain Complex could generate the variation in the $\delta^{18} \mathrm{O}$ ratios. Alternatively, Forester and Taylor (1980) suggested that the wide range might also partially be due to temperature variation.

Craig (1963) reported that meteoric waters could have very positive $8^{18} \mathrm{O}$ values, even as high as those typical of magmatic fluids as a result of exchange with high-temperature country rock. Waters could obtain $8^{18} \mathrm{O}$ values of the magmatic range, simply by coming into contact with igneous rocks at their crystallization temperatures, and by oxygen isotopic exchange (Taylor 1967). Similarly, metamorphic waters can also exchange oxygen with sedimentary rocks, hence increasing the $8^{18} \mathrm{O}$ values (Taylor and Epstein 1962).

Carbon with $\delta^{13} \mathrm{C}$ values of -8 to $-0.5 \%$ could be derived from various reservoirs, given that the average $\delta^{13} \mathrm{C}$ values in igneous, sedimentary and metamorphic rocks is -5 , and that of juvenile carbon is $-5 \pm 27$ oo (Ohmoto and Rye 1979).

Ganor et al. (1994) interpreted the generation of low $\delta^{13} \mathrm{C}$ calcite veins in the Cycladic Complex (Greece) have been generated by oxidation of organic carbon. These veins have $\delta^{\mathrm{J} 3} \mathrm{C}$ values of -12 to $-8 \%$, and high values of $\delta^{18} \mathrm{O}$. They suggested an origin of meteoric or seawater or solution of soil- $\mathrm{CO}_{2}$ in downward percolating rain waters. Extensional brittle tectonic fractures provided a flow path for the fluid during the late stages of exhumation of the Cycladic Complex.

Extensional fractures have been recognized as an important process during the exhumation of metamorphic terranes. Veins generated by downward fluid movement along high or low angle faults and fractures with organic carbon oxidation may therefore be a characteristic feature of such exhumation processes (Ganor et al. 1994).

Source for the second group of carbonate veins still remains unanswered. However, $\delta^{13} \mathrm{C}$ and ${ }^{87} \mathrm{Sr} /{ }^{86} \mathrm{Sr}$ ratios suggest that fluids from crustal sources formed them. A metamorphic and/or meteoric fluid that percolated and interacted with the country rocks before calcite precipitated in the extensional fractures could be suggested.

Fluid inclusion analyses would be useful to confirm this theory. Fluid inclusions in calcite from veins were analyzed at the University of Windsor during the development of the present work. However, problems related to constant linking caused by the opening of cleavage planes, make the obtained data not trustful.

In contrast to the samples from the first vein group, the seven samples from the second group analyzed for ${ }^{87} \mathrm{Sr}{ }^{86} \mathrm{Sr}$ ratios display a wide range of values $(0.7075$ to 0.7144$)$. Only one sample shows a value of 0.7075 , others have values of above 0.7119 .

The second group of carbonates exhibits a range of ${ }^{87} \mathrm{Sr} /{ }^{86} \mathrm{Sr}$ values greater than that of the wall rocks in Cabaçal region (Fig. 6). However, the lack of data from sedimentary country rocks must be considered.

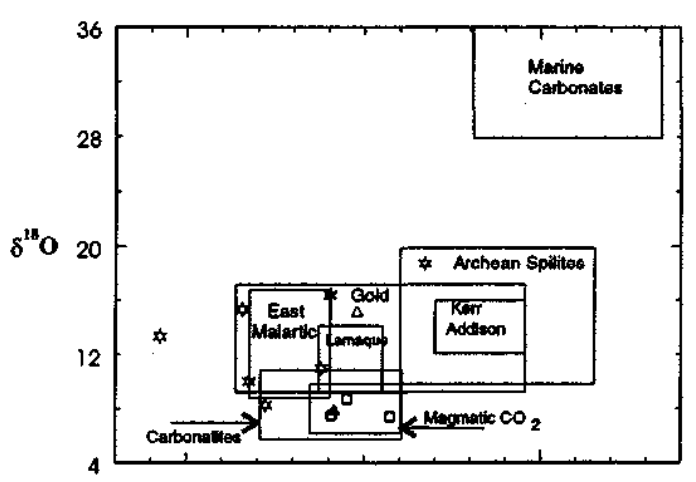

$-10$

0

Figure 4 - Fields of carbonates from different areas; $\mathrm{CO}_{2}$ magmatic derived; and different rocks and areas, plotted in $\delta^{13} C$ versus $\delta^{18} \mathrm{O} O$ diagram. Carbonate vein first group in squares; carbonate vein second group in stars; quartz-carbonate vein in triangles. Modified from Foy (1985), Kerrich(1989), andFyonetal. (1983). $\mathrm{CO}_{2}$ East Malartic and Lamarque fields from Foy (1985), Kerr Addisson field from Fyon et al. (1983); marine carbonates, carbonatites, Archean spilites, and gold fields from Kerrich (1989).

No. of Samples: 10
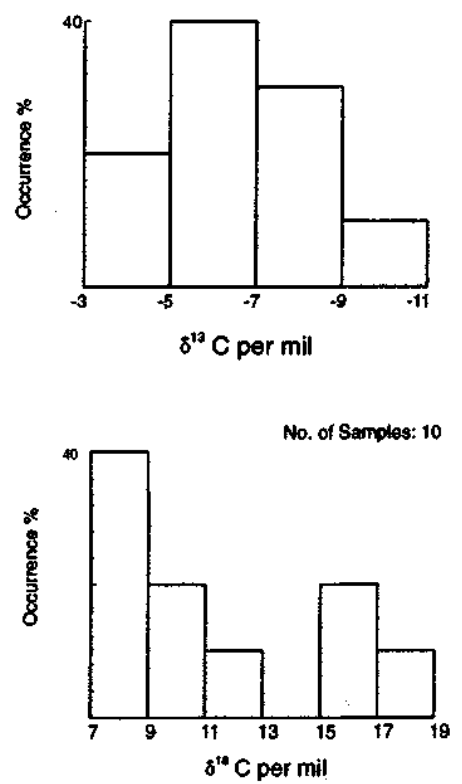

Figure $5-\delta^{\text {io }}$ Cand $\delta^{13}$ O histograms from the Cabaçal Deposit calcite veins.

In general, sedimentary rocks show elevated values of ${ }^{87} \mathrm{Sr} / \mathrm{Sr}$. Norman and Lands (1983) analyzed two samples of shale and quartzite from the Pasto Bueno Deposit, Peru, giving ${ }^{87} \mathrm{Sr} /{ }^{86} \mathrm{Sr}$ ratios of 0.7169 and 0.710 , respectively. Values between 0.710 and 0.713 characterize metasedimentary rocks in the Calaveras Complex (Schweickert 1981). Furthemore, values higher than 0.714 to 0.730 have also been reported for metassedimentary rocks of the Shoo Fly Complex (Bohlke and Kistler 1986).

The variation of ${ }^{87} \mathrm{Sr}{ }^{86} \mathrm{Sr}$ ratio may be explained by the involvement of fluid exchange with the country rocks, including metasedimentary rocks of apparently high ${ }^{87} \mathrm{Sr} /{ }^{86} \mathrm{Sr}$ values. The contribution of metamorphic fluids can be excluded because the second group of veins postdates metamorphism. Therefore, meteoric water or seawater is the most probable fluid.

There are no estimated values of ${ }^{87} \mathrm{Sr}{ }^{86} \mathrm{Sr}$ for meteoric waters from the Cabacal region throughout the geologic history. However, exchange between meteoric water and country rocks is commonly described and recognized to generate a large ${ }^{87} \mathrm{Sr} /{ }^{86} \mathrm{Sr}$ range. Clauer (1981) carried out an experiment by leaching the soluble materials of the saprolite whole rocks from the upper and intermediate zones of the soil profile of the Chad Republic with distilled water. The ${ }^{87} \mathrm{Sr} /{ }^{86} \mathrm{Sr}$ 
Table $1-\delta^{13} C, \delta^{18}$ and ${ }^{87} \mathrm{Sr} /{ }^{86}$ composition of calcite veins from Cabaçal Deposit.

\begin{tabular}{|c|c|c|c|}
\hline Sample & $\delta^{15} \mathrm{C}$ & $8^{15} 0$ & $\mathrm{Sr}^{24} \mathrm{Sr}$ \\
\hline \multicolumn{4}{|c|}{ Carbouale Curst veilo proup } \\
\hline SN-110 & $.5,50$ & 891 & \\
\hline JUADOC 44.00 & -5.77 & $\frac{7.62}{72}$ & 0,7029 \\
\hline JWADD02-38.60 & 4.38 & 7.79 & 0.7029 \\
\hline \multicolumn{4}{|c|}{ Carbonate second vein gronep } \\
\hline SN-1302 & -8.00 & 10.40 & \\
\hline $\mathrm{N} 135 \mathrm{Cam} 1 / 130$ & -6.18 & 10.66 & 0.714 \\
\hline SUD $05-40.75$ & & & 0.7075 \\
\hline TBD02-89.35 & & & 0.713 \\
\hline SP70-34.20 & .7 .84 & 8.20 & \\
\hline SP1 $14-100.00$ & & & 0.7119 \\
\hline SP127.79.90 & -5.90 & 15.99 & $0.71 \mathrm{A4}$ \\
\hline SP420-84,60 & -8.46 & 15.14 & \\
\hline SP435-79.30 & -3.102 & 1803 & \\
\hline \$P435-103.00 & -10.78 & 12.84 & 0.7138 \\
\hline SP435-113,00 & & & 0.7124 \\
\hline \multicolumn{4}{|c|}{ Quartz-cartongte veins } \\
\hline \$P76-101.10 & -5.24 & 16.79 & \\
\hline SP113-81.10 & -5.94 & 8.06 & \\
\hline
\end{tabular}

ratios of the solutions were then analyzed. They varied from 0.709 in the upper part of the profile, through to about 0.715 in the middle part, to approximately 0.765 in the lower part. This experiment shows the possibility in generating a large range of ${ }^{87} \mathrm{Sr} /{ }^{86}$ ratios, when meteoric water percolates crustal rocks.

Faure (1977) reviewed data from Veizer and Compston (1976), Veizer et al. (1983) and Demaiffe and Fieremans (1981) on the variations of ${ }^{87} \mathrm{Sr}{ }^{86} \mathrm{Sr}$ ratios of marine carbonate rocks of Precambrian age. The data suggest that the ${ }^{87} \mathrm{Sr}{ }^{86} \mathrm{Sr}$ ratio of the oceans in Archaean time was similar to that of the $\mathrm{Sr}$ in the mantle until 2.5 billion years ago. The marine ${ }^{87} \mathrm{Sr}{ }^{86} \mathrm{Sr}$ then increased and reached values around 0.7090 in the late Proterozoic time.

The isotope data indicate that different fluids were involved in the deposition of the different generations of carbonate veins. Tentatively, the first group of veins, and the quartz-carbonate vein can be related to igneous processes. Probably, that is the igneous activity that created the volcanic sequence of the Alto Jauru greenstone belt. The second group is believed to have been formed by meteoric or metamorphic fluids that percolated through extension fractures and interacted with the country rocks after the cessation of the tectonic processes. However, the very positive 8 values, remain to be explained.

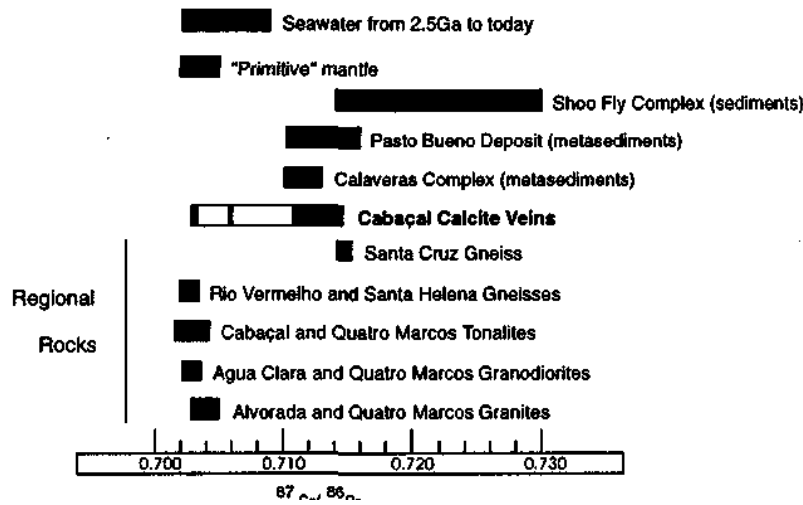

Figure 6 - Sr/ Sr ratio variation for different rocks from Cabaçal region; primitive mantle; seawater; sedimentary rocks from different places; and calcite veins from Cabaçal. Alvorada Granite from Monteiro et al. (1986); Quatro Marcos region rocks: granite, granodiorite and tonalitefrom Cameiro (1985); Agua Clara Granodiorite, Cabaçal Tonalite and Rio Vermelho Gneiss from Leite e Saes (in press); Santa Helena Gneiss from Menezes et al. (1993): Santa Cruz Gneiss from Ruiz (1992); seawater from 2.5Ga to today from (Veizer and Campston 1976, Veizer et al. 1983, Demaiffe and Fireman 1981); "primitive" mantle from various sources in Bohlke and Kistler (1986): Pasto Bueno shale and quartzitefrom Norman and Lands (1983); metassedimentary rocks from Calaveras Complex from Schweickert(1981); and metassedimentary rocks of the Shoo Fly Complex from Bohlke and Kistler (1989).

Acknowledgment To CNPq-Conselho Nacional de Desenvolvimento Cientffico e Tecnol6gico-Brazil, Professor Fred Longstaffe of the Laboratory for Isotopic Studies (University of Western Ontario), Dr. Colombo Tassinari (Universidade de Sao Paulo), and to

\section{References}

Bethke, P. M. and Rye, R. O. 1979. Environment of ore deposition in the Creede Mining district; San Juan Mountains, Colorado: Part IV. Source fluids from oxygen, hydrogen and carbon isotope studies. Economic Geology, 74:1832-1851.

Bohlke, J. K. and Kistler, R. W. 1986. Rb-Sr, K-Ar and stable isotope evidence for the ages and source of fluid components of gold bearing quartz veins in the northern Sierra Nevada Foothills Metamorphic Belt California. Economic Geology, 81, 296-322.

Burrows, D. R.; Wood, P. C.; and Spooner, E. T. C. 1986. Carbon isotope evidence for a magmatic origin for Archean gold-quartz vein ore deposits. Nature, 321, 851-854

Carneiro, M. A. 1985. Contribuição à geologia da regiao de Sao losi dos Quatro Marcos-MT Dissertac5o de Mestrado-USP. 156p.

Clauer, N. 1981. Strontium and argon isotopes in naturally weathered biotites, muscovites, and feldspars. Chem. Geol., 31, 325-334.

Craig, H. 1963. The isotopic geochemistry of water and carbon in geothermal areas. In: E. Tongiorgi (Editor), Nuclear Geology and Geothermal Areas. Consiglio Nationale Delle Recherche. Pisa, pp. 17-53.

Demaiffe, D. and Fieremans. 1981. Strontium isotopic geochemistry of the Mbuji Mayi and Kundelungu Kimberlites (Zaire, central Africa), chem. Geol. 31, 311-324.

Faure, G. 1977. Principles of isotope geology. John Wiley \& Sons. 464 pages.

Faure, G. and Hurley, P. M. 1963. The isotopic composition of strontium in oceanic and continental basalt: application to the origin of igneous rocks. J. Petrol. 4,31-50.

Faure, G. and Powell, J. L. 1972. Strontium Isotope Geology. Springer-Verlag.188p.

Forester, R. W. and Taylor, H. P., Jr. 1980. Oxygen, hydrogen and carbon isotope studies of the Stony Mountain Complex, Western San Juan Mountains, Colorado. Economic Geology, 75, 362-383

Foy, R. 1985. Geology of Kirkland and Larder Lakes, northern Ontario. B. Sc. thesis, University of Western Ontario.

Fyon, J. A.; Crocket, J. H. and Schwarcz, H. P. 1983. Application of stable isotope studies to gold metallurgy in the Timmins-Porcupine camp. Ontario Geoscience Research Grant Program, grant 49, O.G.S. Open File Rep. 5464. 182p.

Ganor, J.; Matthews, A.; and Schliestedt, M. 1994. Post metamorphic low $\delta^{13} \mathrm{C}$ calcite in the Cycladic Complex (Greece) and their implications for modeling fluid infiltration processes using carbon isotopic compositions. Eur. J. Mineral. 6,365-379.

Kerrich, R. 1989. Geochemical evidence on the sources of fluids and solutes for shear zone hosted mesothermal Au deposits. In: J. T. Bursnal, ed., Mineralization and Shear Zones. GAC/MAC Short Course Notes. Vol. 6, 129-197.

Leite, J. A . D. e Saes, G. S. 1995. Evolução Arqueana e do Proteroz6ico Inferior a Mddio da Por ao Sul do CrSton Amazonico no Sudoeste do Estado de Mato Grosso (in press).

Mason, R. and Kerr, D. 1990. Cabaçal 1 Mine-Mato Grosso State, Brasil. Definition of ore zones and potential for new ore reserves. On behalf of Mineragao Santa Martha. Rio de Janeiro, Brasil.

McCrea, J. M. 1950. On the isotopic chemistry of carbonates and paleotemperature scale. Journal of Chemistry and Physics, 18, 849-857.
Menezes, R. G. de; Silva, L. C. da; Silva, P. C. S. da; e Takahashi, A. T. 1993. Geologia da Folha Pontes e Lacerda. In: Menezes, R. G. Programa de Levantamentos Geológicos BSsicos do Brasil, Pontes e Lacerda-Folha SD.21.Y-C-III. Estado de Mato Grosso. Escala 1:100.000. DNPM/CPRM, 27-66.

Mineracao Santa Marta S.A. 1987. Cabacal I Mine - Brazil Internal company report.

Monteiro, H.; Macedo, P. M. de; Silva, M. D. da; Moraes, A. A. de; and Marchetto, C.M. L. 1986 O greenstone belt do Alto Jauru. In: Cong. Bras. Geol. 34. Goiânia-GO. SBG. v.2:630-647.

Norman, D. I. and Landis, G. P. 1983. Source of Mineralizing Components in Hydrothermal Ore fluids as Evidenced by ${ }^{87} \mathrm{Sr}{ }^{86} \mathrm{Sr}$ and Stable Isotope Data from Pasto Bueno Deposit, Peru. Economic Geology, 78,451-465.Miyashiro, A. 1974.

Ohmoto, H. and Rye, R. O. 1979. Isotopes of sulfur and carbon. In: H. L. Barnes, ed., Geochemistry of Hydrothermal Ore Deposits, second ed., 509-567. John Wiley, New York, 798p Pearce, T. H. 1969. A contribution to the theory of variation diagrams.

Pinho, F. E. C. 1996. The origin of the Cu-Au Deposit, Alto Jauru Greenstone Belt, Brazil. Ph.D. Thesis. University of Western Ontario-Canada.

Ruiz, A. S. 1992. Contribuisao a geologia da regiao do Distrito de Cachoeirinha-MT. Exame de Qualificac5o-USP. 118p

Schweickert, R. A. 1981. Tectonic evolution of the Sierra Nevada range, in: Ernst, W. G., ed., The geotectonic evolution of the California; Englewood Cliffs, New Jersey, Prentice-Hall. p. 87-131.

Sharma, T. and Clayton, R. N. 1965. Measurement of ${ }^{18} \mathrm{O} /{ }^{16} \mathrm{O}$ ratios of total oxygen of carbonates. Geochimica et Cosmochimica Acta, 29, 1347-1354.

Taylor, H. P.., Jr. 1967. Oxygen Isotope Studies of Hydrothermal Mineral Deposits. In: Hubert Lloyd Barnes (ed.) Geochemistry of Hydrothermal Ore Deposits. Holt, Rinehart and Winston, Inc. pp. 109-142.

Taylor, H. P., Jr. and Epstein, S. 1962 . Relationship between ${ }^{18} \mathrm{O} /{ }^{16} \mathrm{O}$ ratios in coexisting minerals of igneous and metamorphic rocks, part 2, application to petrologic problems. Bull. Geol. Soc. Am., 73, 675-694.

Veizer, J.; Compston, W.; Clauer, N.; and Schidlowski, M. 1983. ${ }^{\wedge} \mathrm{Sr} / \wedge \mathrm{Sr}$ in Late Proterozoic carbonates: evidence for a "mantle" event at -900 Ma ago*. Geochimica et Cosmochimica Acta. Vol. 47, 295-302.

Veizer, J. and Compston, W. $1976 .{ }^{87} \mathrm{Sr} /{ }^{86} \mathrm{Sr}$ in Precambriam carbonates as an index of crustal evolution. Geochimica et Cosmochimica Acta. Vol. 40,905-914.

Wood, D. A. 1980. The application of Th-Hf-Ta diagram to problems of tectonomagmatic classification and to establish the nature of crustal contamination of basaltic lavas of the British Tertiary volcanic province. Earth Planet. Sci. Lett., 50:11-30

Manuscrito A-1025

Recebido em 19 de agosto de 1998 Revisao dos autores em 30 de marco de 1999 Revisao aceita em 5 de abril de 1999 